\title{
Persepsi Masyarakat Tentang Keberadaan Bank Syariah Indonesia Cabang Pembantu Stabat
}

\author{
Anjur Perkasa Alam¹, Asmawarna Sinaga ${ }^{2}$, Fitra Alpa Syafira ${ }^{3}$, Rio Ramadhan Putra ${ }^{4}$ \\ 1,2,3,4 Sekolah Tinggi Agama Islam Jam'iyah Mahmudiyah Tanjung Pura
}

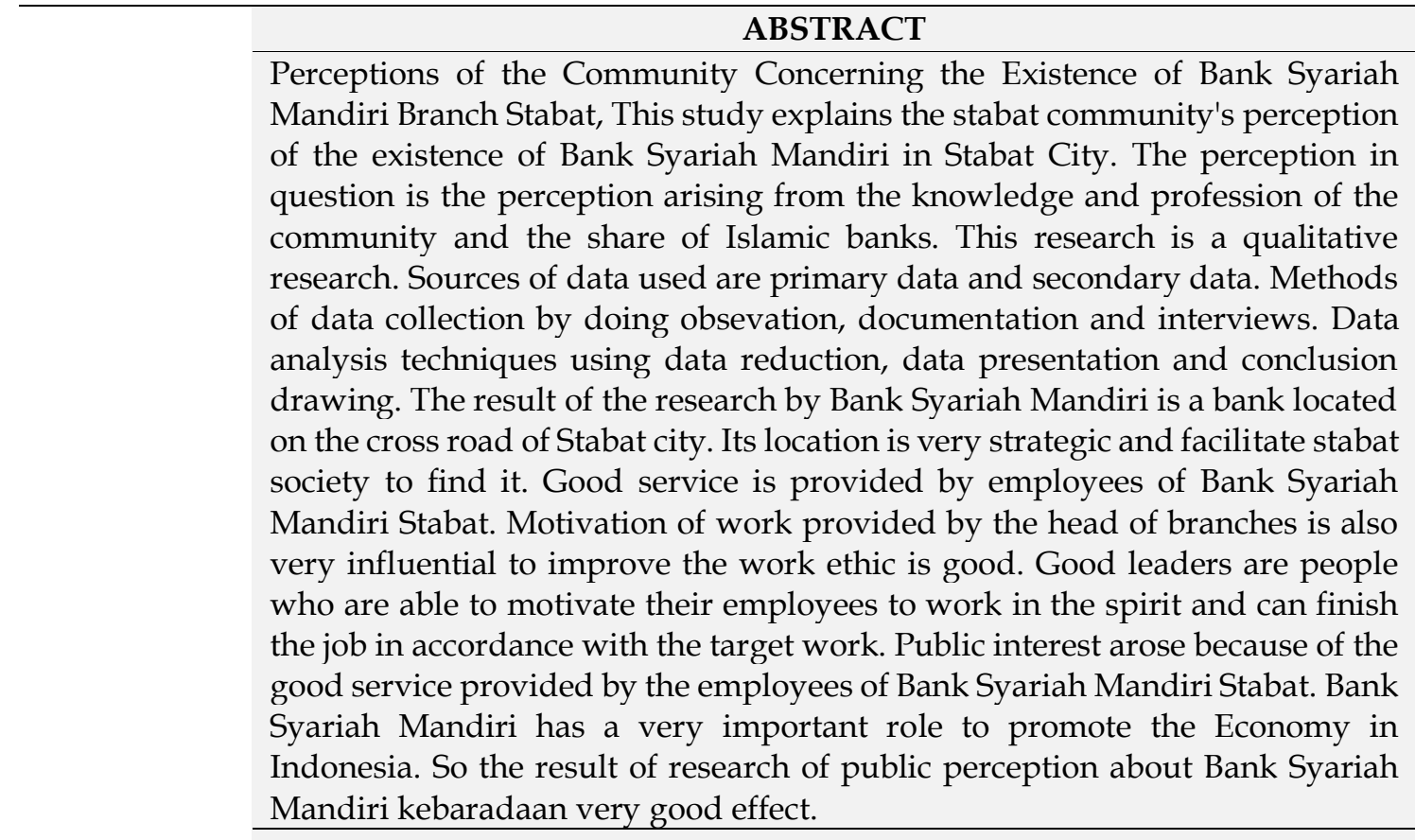

Kata Kunci

Perceptions, Interests, For Results. Islamic Bank

\section{PENDAHULUAN}

Bisnis di Indonesia dari masa ke masa terasa semakin kompetitif. Meskipun sebenarnya kondisi perekonomian Indonesia secara umum belum menunjukkan adanya perbaikan dan peningkatan yang signifikan. Namum bukan berarti terjadi kondisi yang stagnasi dalam dunia bisnis. Setiap perushaan selalu berusaha untuk dapat bertahan dalam arus persaingan bisnis, terlebih lagi bagi lokal. Sebagai lembaga keuangan yang mendapatkan kepercayaan masyarakat atas dananya, bank semaksimal mungkin melakukan daya tarik ekonomi berupa bunga tinggi, bonus serta hadiah yang menarik. Berbagai cara dilakukan bank dengan tujuan meningkatkan penghimpunan dana dari masyarakat yang salah satu caranya adalah meningkatkan volume nasabahnya (Parwatatmaja, 1996).

Perbankan syariah dalam istilah internasional dikenal sebagai Islamic Banking atau disebut dengan interest-free banking. Seperti halnya bank Konvensional, bank syariah mempunyai fungsi utama yaitu menghimpun dana 
masyarakat dan menyalurkan kembali dana tersebut ke masyarakat serta memberi jasa bank lainnya (Muhammad, 2011).

Bank syariah ini lahir sebagai solusi alternatif terhadap persoalan pertentangan antara bunga bank dengan riba. Riba berarti menetapkan bunga atau melebihkan jumlah pinjaman pokok secara bathil. Dalam praktik perbankan konvensional terdapat kegiatan yang dilarang syariat islam, seperti praktik riba, membiayai produksi dan perdagangan barang terlarang, misalnya minuman keras. Untuk menghindari pengoperasian sistem bunga, lahirlah perbankan syariah yang sesai dengan prinsip syariah kedalam transaksinya. Hal yang membedakan antara lembaga pembagian keuntungan yang diberikan oleh lembaga keuangan kepada nasabah. Bank syariah mempunyai prinsip bagi hasil yang sangat berbeda dengan bank Konvensional. Perbedaan yang paling mendasar adalah pada bagian memperoleh keuntungan, dimana pada bank konvensional terkenal dengan perangkat bunga, sedangkan pada bank syariah melarang adanya bunga yaitu dengan menggunakan prinsip bagi hasil (Antonio, 2001).

Perkembangan Bank Syariah di Indonesia cukup berkembang pesat, walaupun demikian, jumlah bank maupun kantor bank yang sudah cukup banyak, namun jumlah aset bank syariah masih kecil dibandingkan dengan bank konvensional. Perbankan syariah yang masih muda umurnya, dituntut untuk bersaing dengan bank konvensional. Perbankan syariah juga dituntut untuk memainkan peranan yang sangat vital dalam menggerakkan roda perekonomian bangsa Indonesia.

Persaingan nasabah atau tuntutan nasabah terhadap pelayanan bank yang lebih sempurna merupakan adanya pendorong inovasi dan adanya perubahan bisnis perbankan. Pihak bank telah mengakui dan menyadari apa yang diinginkan nasabah dan memilih apa yang terbaik. Dipihak lain, nasabah juga tidak menginginkan prosedur yang panjang dan rumit untuk setiap transaksinya. Kenyamanan dan kemudahan sudah menjadi tujuan perbankan syariah. hadirnya perbankan syariah di Indonesia membawa dampak positif bagi kemajuan perekonomian. Dari awal munculnya hingga sekarang perbankan syariah dapat bertahan dengan memunculkan beragam produk dan memberikan berbagai keuntungan yang ditawarkan kepada nasabahnya. Salah satu Bank Syariah yang mempunyai peran penting dan perkembangan perbankan Syariah di Indonesia adalah Bank Syariah Indonesia. Pada hari senin tanggal 1 November 1999 atau bertepatan dengan 25 Rajab $1420 \mathrm{H}$ merupakan hari pertama beroperasinya PT. Bank Syariah Mandiri. Lahirnya Bank Syariah Mandiri merupakan buah usaha bersama dari para perintis bank syariah di PT. Bank 
Susila Bakti dan Manajemen PT. Bank Mandiri yang memandang pentingnya kehadiran Bank Syariah di lingkungan PT. Bank Mandiri.

Tingkat persaingan bank syariah tidak hanya sesama bank syariah melainkan juga bank Konvensional. Oleh karena itu salah satu perbandingan yang sangat penting harus dimiliki oleh bank syariah adalah unggul dalam pelayanan. Dalam pelayan tidak terlepas dari etika pegawai bank, karena etika pegawai bank sangat berpengaruh terhadap nasabah (Soejitno \& Abdul, 2004). Bank Syariah mulai melebarkan cabang kantornya disetiap wilayah di Indonesia. Hampir disetiap provinsi, kotamadya, kabupaten bahkan kecamatan bisa kita temui bank syariah. Persepsi masyarakat pun bermunculan tentang keberadaan bank syariah, khususnya Bank Syariah Indonesia.

\section{Pengertian Persepsi}

persepsi secara etimologi disebut dengan pandangan, gambaran, atau anggapan. Sebab didalam persepsi terdapat tanggapan seseorang mengenai satu hal atau objek. Persepsi adalah "proses yang menyangkut masuknya pesan atau informasi kedalam otak manusia, melalui persepsi manusia terus menerus mengadakan hubungan dengan lingkungannya. Hubungan ini dilakukan lewat indranya, yaitu dengan penglihatan, pendengaran, peraba, dan perasa (Slameto, 2010). Jadi dapat disimpulkan perserpsi itu adalah tanggapan yang akan disampaikan mengenai keberadaan sesuatu hal. Tanggapan itu bisa baik atau buruk, tergantung seseorang menilainya.

Bank Syariah Indonesia merupakan salah satu perbankan syariah yang ada di Indonesia. Bank Syariah Indonesia sudah memperluas cabangnya sampai kepelosok negeri selama masa Marger dari tiga Bank Umum milik pemerintah. Salah satu cabang nya terdapat di kota Stabat. Keberadaan Bank Syariah Indonesia menarik minat sebagian besar masyarakat Stabat, untuk bergabung menjadi nasabah.

Menurut kamus populer Bahasa Indonesia nasabah adalah “ orang yang biasa berhubungan dengan atau menjadi pelanggan bank" (Soetrisno, 2010). Menurut kamus ilmiah populer nasabah adalah "pertalian; perhubungan; perbandingan; sahabat; ansab; saudara; kerabat; langganan; pelanggan". Berdasarkan pejelasan diatas dapat disimpulkan bahwa nasabah adalah orang yang menjadi pelanggan di sebuah bank.Dengan demikian semakin meningkatnya persaingan, maka semakin penting peranan kebijakan promosi dalam meningkatkan minat nasabah bank. Kegiatan promosi yang merupakan bagian dari pemasaran sebagai alat yang sangat penting serta turut menentukan suksesnya suatu produk guna meningkatkan minat nasabah.Dewasa ini industri perbankan merupakan salah satu mitra usaha yang dapat dipercaya dalam membantu kelancaran suatu usaha, dengan berbagai fasilitas pembiayaan dari 
bank yang tersedia. Bank adalah salah satu lembaga keuangan yang bergerak di bidang pelayanan jasa, harus dapat memberikan pelayanan yang terbaik (service excellent) untuk dapat memenangkan persaingan yang semakin hari semakin kopetitif. Untuk menghadapi persaingan antara lembaga perbankan yang semakin ketat, sekarang ini telah dikembangkan dalam berbagai konsep pelayanan nasabah dengan tujuan untuk mempertahankan nasabah dan menjangkau nasabah-nasabah potensial.

\section{Fungsi Bank}

Didirikannya Bank Syariah dilatar belakangi oleh keinginan umat islam untuk menghindari riba dalam kegiatan muamalahnya : memperoleh kesejahteraaan lahir batin melalui kegiatan muamalah yang sesuai dengan perintah agamanya. Adapun Bank Syariah merupakan lembaga keuangan yang berfungsi sebagai perantara bagi pihak yang berkelebihan dana dengan pihak yang kekurangan dana untuk kegiatan usaha dan kegiatan lainnya sesuai dengan hukum Islam (Ali, 2008). Bank Syariah juga biasa disebut Islamic Banking atau Interest fee Banking, yaitu suatu sistem perbankan dalam pelaksanaann operasionalnya tidak menggunakan sistem bunga (riba), spekulasi (masisir),dan ketidak pastian atau ketidak jelasan (gharar). Allah SWT berfirman dalam surah Al-Baqarah : 278, yaitu :

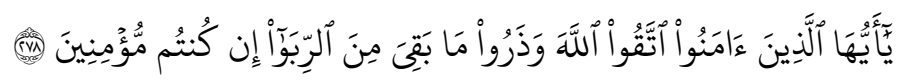

Artinya : "Hai orang-orang yang beriman, bertakwalah kepada Allah dan tinggalkan sisa riba (yang belum dipungut) jika kamu orang-orang yang beriman.

Ayat di atas menjelaskan tentang riba, namun persoalan riba tersebut bukan termasuk dalam akad perbankan. Sebagai mana firman Allah SWT dalam surah Al-Maidah : 1, yaitu :

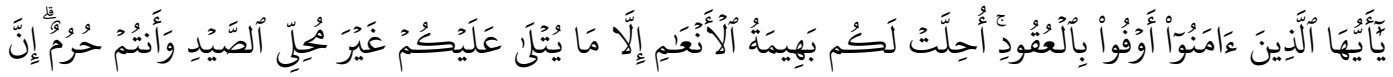

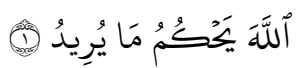

Artinya: "Hai orang-orang yang beriman, penuhilah aqad-aqad itu. dihalalkan bagimu binatang ternak, kecuali yang akan dibacakan kepadamu. (yang demikian itu) dengan tidak menghalalkan berburu ketika kamu sedang

Nasabah adalah kunci dari kesuksesan sebuah bank. Persaingan didunia perbankan saat ini sangat ketat dalam hal mencari nasabah. Berbagai jenis keunggulan yang ditawarkan oleh bank untuk menarik minat nasabah menyimpan uang atau menanbung di bank tersebut.

Nasabah yang memiliki minat dapat mengekspresikannya melalui pernyataan yang menunjukkan bahwa mereka menyukai suatu hal dari pada hal yang lain, dapat pula mereka memanifestasikan melalui partisipasi dalam suatu aktivitas, sebagaimana yang dikatakan oleh Slameto bahwa " seseorang yang 
memiliki minat terhadap subyek tertentu cenderung untuk memberikan perhatian yang lebih besar terhadap subyek tersebut" (Slameto, 2002).

Dari segi lokasi yang sangat mudah dijangkau oleh para nasabah, yang terletak dipinggir kota Stabat. Pelayanan yang ramah tamah, sopan santun dan kekeluargaan. Tingkat keamanan yang memberikan kenyamanan bagi nasabah ataupun calon nasabah yang ingin bergabung di Bank Syariah Indonesia. Tingkat suku bunga yang cukup rendah membuat nasabah semakin yakin untuk menyimpan uang di Bank Syariah Indonesi. Keuanggulan yang dimiliki Bank Syariah, mereka tidak memakai sistem bunga, akan tetapi sistem bagi hasil yang sangat diminati bagi setiap nasabahnya yang ingin meminjam uang di Bank Syariah.

\section{METODE PENELITIAN}

Metode Penelitian ini adalah penelitian kualitatif yang bersifat normatif dengan berdasarkan kepada fakta yang terjadi dilapangan yaitu suatu penelitian yang dilakukan secara sistematis dengan mengangkat data yang ada di lapangan, dimana penelitian dilakukan pada masyarakat langkat yang terletak di Stabat, dan penelitian ini dilakukan dengan melihat hal-hal yang berkaitan dengan masalah yang akan diteliti, yaitu mengenai persepsi masyarakat tentang keberadaan Bank syariah Indonesia cabang pembantu stabat tersebut.

\section{HASIL DAN PEMBAHASAN}

\section{Perasepsi Masyarakat Tentang Bank Syariah Indonesia}

Persepsi masyarakat tentang Bank Syariah adalah bank yang menjalankan sesuai dengan prinsip syariah. Dimana yang dimaksud dengan prinsip syariah adalah aturan perjanjian berdasarkan hukum islam antara bank dan pihak lain untuk menyimpan dana dan atau pembiayaan untuk kegiatan lainnya yang dinyatakan sesuai dengan syariah, antara lain pembiayaan berdasarkan prinsip bagi hasil, pembiayaan berdasarkan prinsip penyertaan modal, prinsip jual beli barang dengan memperoleh keuntungan, atau pembiayaan berdasarkan prinsip sewa murni tanpa pilihan, atau dengan adanya pilihan pemindahan kepemilikan atas barang yang disewakan dari pihak bank ke pihak lain.

Menurut Undang-undang RI Nomor 10 Tahun 1998 tanggal 10 November 1998 tentang perbankan adalah badan usaha yang menghimpun dana dari masyarakat dalam bentuk-bentuk lainnya dalam rangka meningkatkan taraf hidup rakyat banyak (Kasmir, 2010). Sedangkan Menurut Undang-undang Nomor 21 tahun 2008 tentang perbankan syariah, "Perbankan Syariah" adalah segala sesuatu yang menyangkut tentang bank syariah dan unit usaha syariah, mencakup kelembagaan, kegiatan usaha, cara dan proses dalam melaksanakan 
kegiatan usahanya Dengan demikian perbankan syariah dapat dipahami secara detail. Bank syariah adalah lembaga keuangan yang disesuaikan dengan prinsipprinsip syariah. Kehidupan individu tidak lepas dari lingkungan sosialnya, baik lingkungan fisik maupun lingkungan keluarga. Sejak individu dilahirkan, sejak itu pula individu berhubungan langsung dengan dunia sekitarnya. Mulai saat itu pula individu secara langsung menerima stimulus dari luar dirinya, dan hal ini berkaitan dengan persepsi.

Manusia mempunyai persepsi yang berbeda terhadap sesuatu baik dilihat dari faktor pengetahuan ataupun pengalamannya terhadap suatu kejadian. Persepsi adalah suatu proses aktif setiap orang memperhatikan, mengorganisasikan, dan menafsirkan semua pengalamannya secara selektif (Mulyana, 2000). Persepsi individu hakikatnya dibentuk oleh budaya karena ia menerima pengetahuan dari generasi sebelumnya. Pengetahuan yang diperolehnya itu digunakan untuk memberi makna bagi mereka. Persepsi adalah pengalaman tentang objek, peristiwa, atau hubungan yang diperoleh dengan menyimpulkan informasi dan menafsirkan pesan dan memberikan makna pada stimulasi inderawi (Rakhmat, 20001).

Persepsi juga merupakan suatu proses pengenalan individu pada informasi, memperhatikan dan memahami informasi. Jadi pada dasarnya persepsi adalah pola respon seseorang tentang sesuatu yang dipengaruhi oleh faktor kesiapan, tujuan, kebutuhan, pengetahuan, pengalaman, dan faktor lingkungan.

Ada beberapa faktor yang mempengaruhi persepsi seseorang, yaitu :

1. Faktor yang berada dalam diri yang mempersepsikan berupa sikap, alasan, atau sebab, minat, pengalaman, dan dugaan.

2. Faktor yang berada dalam objek yang dipersepsikan berupa sesuatu yang baru, suara, ukuran, latar belakang dan dekatnya,

3. Faktor yang berada dalam situasi, berupa bentuk, keadaan pekerjaan sosial setting (Robin, 2001).

Persepsi masyarakat Stabat mengenai keberadaan Bank Syariah Mandiri sangat baik. Hal ini dibuktikan dengan makin banyaknya masyarakat Stabat yang ingin menjadi nasabah di Bank Syariah Mandiri. Bank Syariah Mandiri hadir dengan menggunakan sistem bagi hasil, bukan bunga.

Allah SWT berfirman mengenai riba dalam surat An Nisa ayat 161, yaitu:

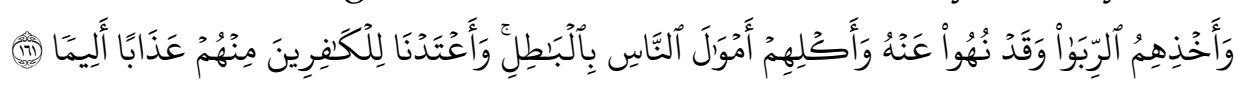

Artinya :"Dan disebabkan mereka memakan riba, padahal Sesungguhnya mereka Telah dilarang daripadanya, dan Karena mereka memakan harta benda orang dengan jalan 
yang batil. kami Telah menyediakan untuk orang-orang yang kafir di antara mereka itu siksa yang pedih".

Permasalahan riba inilah yang menjadi tolak ukur nasabah lebih memilih menyimpan uangnya di Bank Syariah. Sistem bagi hasil yang ditawarkan oleh Bank Syariah ini lah yang sangat menarik minat nasabah. Adapun pengertian riba adalah pengambilan tambahan, baik dalam transaksi jual beli maupun pinjam meminjam secara batil atau bertentangan dengan prinsip muamalah dalam islam (Antonio, 2001). Dalam hal ini mudharabah bukan termasuk riba, karena mudharabah adalah sisitem bagi hasil yang diperbolehkan oleh Rasulullah Saw sebagaimana telah dijeaskan dalam hadis, yaitu :

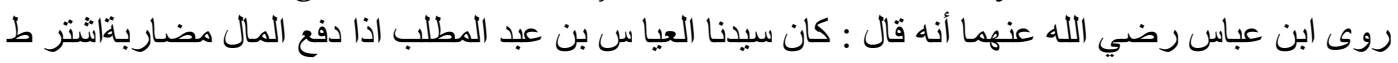

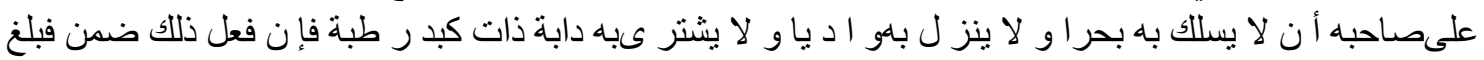

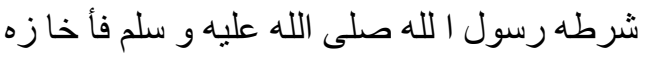
Artinya: "Diriwayatkan dari Ibnu Abbas bahwa sayyidina Abbas bin Abdul Muthalib jika memberikan dana ke mitra usahanya secara mudharabah ia mensyaratkan agar dananya tidak dibawa mengarungi lautan, menuruni lembah yang berbahaya, atau membeli ternak. Jika menyalahi peraturan tersebut, yang bersangkutan bertanggung jawab atas dana tersebut. Disampaikanlah syarat-syarat tersebut kepada Rasulullah Saw, dan Rasulullah pun membolehkannya". (HR Thabrani)

Setiap manusia memiliki kecenderungan yang fundamental untuk berhubungan dengan sesuatu yang berada dalam lingkungannya, jika hal tersebut memberikan kesenangan pada dirinya kemungkinan dia akan berminat terhadap sesuatu tersebut.

Minat muncul apabila seseorang tertarik kepada sesuatu karena sesuai dengan kebutuhannya atau merasakan bahwa sesuatu itu berguna bagi dirinya. Kebutuhan disini yaitu seperti kebutuhan akan aktualisasi diri, kebutuhan estetis, kebutuhan kognitif, kebutuhan akan penghargaan, kebutuhan cinta dan rasa memiliki, kebutuhan akan keamanan dan kebutuhan fisiologi (Grove, 2000).

Dilihat dari segi bahasa minat berarti "kecenderungan hati yang tinggi terhadap sesuatu, gairah, keinginan". Menurut WJS. Poerwadarminta dalam kamus umum Bahasa Indonesia menyatakan bahwa minat adalah perkataan atau ungkapan, kesukaan (kecenderungan hati) kepada sesuatu (Poerdarminta, 1992). Slameto berpendapat minat adalah " suatu rasa lebih suka dan rasa ketertarikan pada suatu hal atau aktivitas tanpa ada yang menyuruh" (Slameto, 2002).

Dari beberapa pendapat ahli psikologis diatas, dapat disimpulkan minat adalah suatu kecenderungan yang erat kaitannya dengan perasaan terutama perasaan senang terhadap sesuatu yang dianggap berharga atau sesuai 
kebutuhan dan memberikan kepuasan kepadanya. Sesuatu itu dapat berupa aktivitas orang,

Bank Syariah adalah bank yang tata cara operasinya mengikuti ketentuanketentuan syariah Islam". Salah satu yang harus dijauhi dalam muamalah Islam adalah praktik-praktik yang mengandung unsur riba. Sedangkan menurut Bank Syariah adalah Bank yang beroperasi dengan tidak mengandalkan pada bunga. Yakni mengacu kepada ketentuan-ketentuan Al-quran dan Hadis (Ismail, 2011).

Dimana yang dimaksud dengan perbankan syariah adalah segala sesuatu yang menyangkut tentang Bank Syariah dan Unit Usaha Syariah, mencakup kelembagaan, kegiatan usaha, serta cara dan proses dalam melaksanakan kegiatan usahanya. Perbankan Syariah merupakan bank yang menerapkan nilainilai syariah salah satu diantaranya pelarangan unsur riba, seperti dijelaskan di beberapa ayat Al-Qur'an dalam Surat Al-Imran :130 sebagai berikut :

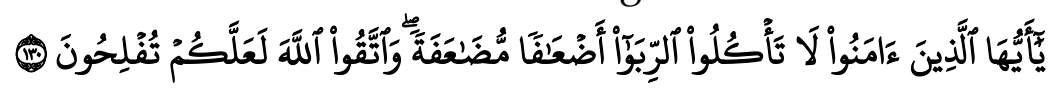

Artinyan : "Hai orang-orang yang beriman, janganlah kamu memakan riba dengan berlipat ganda dan bertakwalah kamu kepada Allah supaya kamu mendapat keberuntungan".

Dari ayat diatas, dapat dijelaskan tentang pengertian riba, yaitu : yang dimaksud riba di sini ialah riba nasi'ah. menurut sebagian besar ulama bahwa riba nasi'ah itu selamanya Haram, walaupun tidak berlipat ganda. Riba itu ada dua macam: nasiah dan fadhl. riba nasiah ialah pembayaran lebih yang disyaratkan oleh orang yang meminjamkan. riba fadhl ialah penukaran suatu barang dengan barang yang sejenis, tetapi lebih banyak jumlahnya Karena orang yang menukarkan mensyaratkan demikian, seperti penukaran emas dengan emas, padi dengan padi, dan sebagainya. riba yang dimaksud dalam ayat Ini riba nasiah yang berlipat ganda yang umum terjadi dalam masyarakat Arab zaman Jahiliyah.

Allah Swt berfirman mengenai riba dalam An Nisa : 161, yaitu :

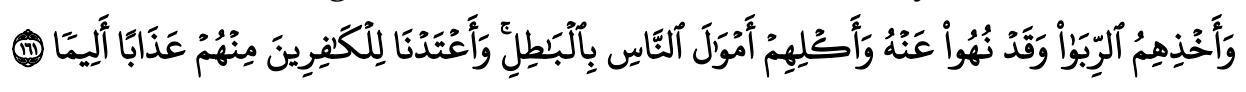

Artinya :"Dan disebabkan mereka memakan riba, padahal Sesungguhnya mereka Telah dilarang daripadanya, dan Karena mereka memakan harta benda orang dengan jalan yang batil. kami Telah menyediakan untuk orang-orang yang kafir di antara mereka itu siksa yang pedih".

Permasalahn riba inilah yang menjadi tolak ukur nasabah lebih memilih menyimpan uangnya di Bank Syariah. Sistem bagi hasil yang ditawarkan oleh Bank Syariah ini lah yang sangat menarik minat nasabah.

$$
\text { عن صالح بن صهيب عن ابيه قال: قال رسول الله صلى الله عليه وسلم ثلاث فيهن البيع الى اجل و المقارضة و اخلاط }
$$


Artinya: "Dari Shahih bin Shuhaib r.a. bahwa Rasulullah saw. Bersabda, "Tiga hal yang di dalamnya terdapat keberkatan: jual beli secara tangguh, muqaradhah (mudharabah), dan mencampur gandum dengan tepung untuk keperluan rumah, bukan untuk dijual". (HR. Ibnu Maja)

Dari hadis di atas, dapat dijelaskan tentang pengertian riba, yaitu : yang dimaksud riba di sini ialah riba nasi'ah. menurut sebagian besar ulama bahwa riba nasi'ah itu selamanya Haram, walaupun tidak berlipat ganda. Riba itu ada dua macam: nasiah dan fadhl. riba nasiah ialah pembayaran lebih yang disyaratkan oleh orang yang meminjamkan. riba fadhl ialah penukaran suatu barang dengan barang yang sejenis, tetapi lebih banyak jumlahnya.

Karena orang yang menukarkan mensyaratkan demikian, seperti penukaran emas dengan emas, padi dengan padi, dan sebagainya. riba yang dimaksud dalam ayat Ini riba nasiah yang berlipat ganda yang umum terjadi dalam masyarakat Arab zaman Jahiliyah.

Permasalahan riba inilah yang menjadi tolak ukur nasabah lebih memilih menyimpan uangnya di Bank Syariah. System bagi hasil yang ditawarkan oleh Bank Syariah ini lah yang sangat menarik minat nasabah. Allah Swt berfirman dalam surat Al-Baqarah : 275, yaitu :

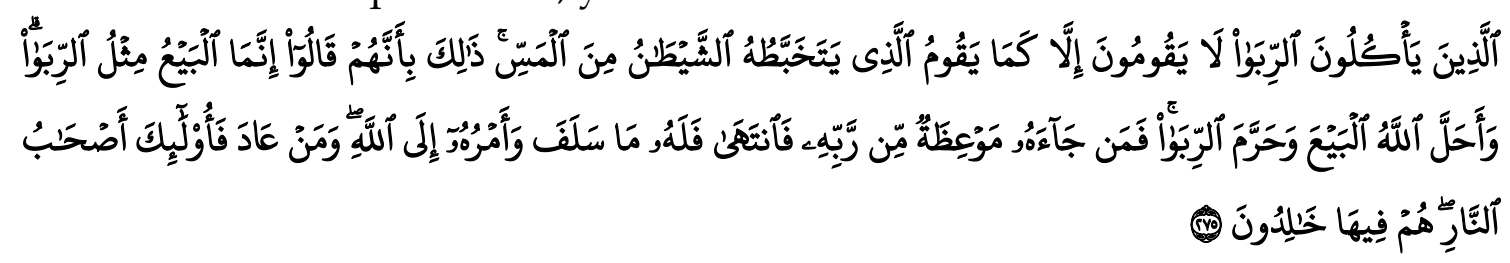

Artinya: "Orang-orang yang makan (mengambil) riba tidak dapat berdiri melainkan seperti berdirinya orang yang kemasukan syaitan lantaran (tekanan) penyakit gila. Keadaan mereka yang demikian itu, adalah disebabkan mereka berkata (berpendapat), sesungguhnya jual beli itu sama dengan riba, padahal Allah telah menghalalkan jual beli dan mengharamkan riba. Orang-orang yang telah sampai kepadanya larangan dari Tuhannya, lalu terus berhenti (dari mengambil riba), maka baginya apa yang telah diambilnya dahulu (sebelum datang larangan); dan urusannya (terserah) kepada Allah. Orang yang kembali (mengambil riba), maka orang itu adalah penghuni-penghuni neraka; mereka kekal di dalamnya".

Selain itu, berdirinya perbankan syariah tentu saja memiliki tujuan secara umum dan khusus. Secara umum tuujuan didirikannya perbankan syariah adalah dapat memberikan sumbangan terhadap pertumbuhan ekonomi masyarakat melalui pembiayaan yang dikeluarkan oleh perbankan syariah. Kemudian secara khusus tujuan bank syariah adalah :

a. Menjadi perekat nasionalisme baru, artinya bank syariah dapat menjadi fasilitator aktif bagi tebentuknya jaringan ekonomi syariah, 
b. Memberdayakan ekonomi masyarakat dan beroperasi secara transparan, artinya pengelolaan bank syariah harus didasarkan pada visi ekonomi kerakyatan dan upaya ini terwujud bila ada mekanisme operas yang transparan,

c. Mendorong penurunan spekulasi di pasar keuangan, artinya bank syariah lebih mengarahkan dananya pada transakasi peroduktif,

d. Meningkatkan efisiensi mobilisasi dana,

e. Uswah hasanah sebahai implementasi moral dalam penyelenggaraan usaha bank (Muhammad, 2006).

Bank syariah memiliki beberapa ciri-ciri dan karakteristik antara lain:

1. Berdimensi keadilan

Ciri ini dilakukan dengan bagi hasil (mudarabah dan musyarakah). Dengan bagi hasil ini tidak muncul kerugian yang hanya dialami oleh salah satu pihak, karena resiko kerugian dan keuntungan yang diperoleh ditanggung bersama antara bank dengan nasabahnya.

Dengan demikian, kekayaan tidak akan hanya beredar pada golongan tertentu. Dengan cara ini pula perekonomian umat akan terwujud secara merata, dari ciri pertama ini akan memungkinkan terjadinya perluasan kesempatan kerja bagi semua lapisan masyarakat, tanpa membedakan antara yang memiliki modal dengan kaum dhu'afa. Hal ini disebabkan prinsip bagi hasil akan mendorong orang melakukan investasi langsung berupa pembiayaan proyek dan perdagangan yang dapat membuka ladang-ladang usaha baru dan kaum dhu'afa juga dapat terlibat di dalamnya.

2. Adanya pemberlakuan jaminan

Ciri ini seiring dengan pasal 8 UU Nomor 7 tahun 1992 tentang perbankan, yang berbunyi: "dalam memberikan kredit, bank umum wajib mempunyai keyakinan atas kemampuan dan kesanggupan debitur mengambilkan uangnya, anggunan dapat hanya berupa barang, proyek atau hak tagih yang dibiayai dengan kredit yang bersangkutan....". (Awaluddin, 2011) Pada bank syariah, yang dijadikan sebagai jaminan adalah proyek yang tengah dikerjakan bersama antara bank dengan pemilik modal dengan nasabah sebagai pengelolah usaha. Sedangkan pada bank konvensional yang dijadikan jaminan adalah kekayaan peminjam. Oleh karena itu, idealnya suatu saat bank syariah mampu meratakan kesempatan berusaha bagi semua lapisan masyarakat yang memiliki potensi bisnis.

3. Menciptakan rasa kebersamaan

Dalam operasionalnya bank syariah berupaya menciptakan kebersamaan antara dirinya sebagai pemilik modal dengan nasabahnya sebagai pengelola modal (Perwaatmadja dan M. Syafi'I Antonio, 1997). Hal ini sejalan dengan salah 
satu prinsip muamalah, yakni memelihara prinsip-prinsip keadilan dan kebersamaan, serta menghindari unsur-unsur penganiayaan dan pengambilan kesempatan dalam kesempitan.

\section{Bersifat mandiri}

Karena prinsip operasional bank syariah tidak menggunakan bunga, maka secara otomatis akan terlepas dari gejolak moneter, dalam negeri maupun internasional. Oleh karena itu, bank syariah dengan sendirinya tidak menggantungkan dirinya pada moneter, sehingga dapat berjalan tanpa dipengaruhi oleh inflasi dan bank syariah mendorong investasi, pembukaan lapangan kerja baru dan pemerataan kesempatan usaha. Lebih jauhnya, bank syariah berperan dalam mengentaskan kemiskinan yang kini tengah dipropagandakan dan digalakkan.

5. Persaingan secara sehat

Sebagaimana telah dikemukakan di atas bahwa bank syariah hadir untuk kemaslahatan umat. Oleh karena itu, bentuk persaingan terjadi antar bank syariah dengan berlomba-lomba untuk lebih tinggi dari yang lain dalam memberikan porsi bagi hasil kepada nasabah.

6. Adanya dewan pengawas syariah

Ciri lain dari bank syariah sebagai pembeda dengan bank konvensional adalah adanya dewan pengawas syariah (DPS) yang bersifat independen, yang dibentuk oleh Dewan Pengawas Nasional (DSN) dan ditempatkan pada bank yang melakukan kegiatan usaha berdasarkan syariah berfungsi sebagai penasehat dan pemberi saran kepada direksi, pemimpin unit usaha syariah, dan pemimpin kantor KCP syariah. Dengan demikian identitas dari bank syariah yang paling membedakan dari bank konvensional adalah adanya dewan pengawas syariah.

\section{KESIMPULAN}

Berdasarkan hasil penelitian yang dilakukan maka dapat disimpulkan bahwa Bank Syariah Indonesia Stabat memberikan persepsi yang baik mengenai keberadaannya di Stabat. Sistem kerja yang bersifat kekeluargaan juga salah satu pengaruh yang baik. Secara garis besar dapat disimpulkan bahwa:

1. Bank Syariah Indonesia memiliki peranan yang sangat penting untuk memajukan perekonomian Islam.

2. Para karyawan yang bekerja di BSI memiliki motivasi yang tinggi, sehingga etos kerja mereka berjalan dengan baik dan sesuai dengan target kerja yang diinginkan. 
3. Kepemimpinan kepala cabang sangat berpengaruh untuk meningkatkan etos kerja karyawan BSI. Pemimpin yang adil dan tegas yang sangat diperlukan, agar karyawan bekerja sesuai dengan tugas nya masing-masing.

4. Motivasi kerja yang diberikan oleh kepala cabang juga sangat berpengaruh untuk meningkatkan etos kerja yang baik. Pemimpin yang baik adalah orang yang mampu mamotivasi karyawannya agar semangat dalam bekerja dan bisa menyelesaikan pekerjaan sesuai dengan target kerja.

5. Pandangan masyarakat Stabat sangat baik mengenai keberadaan BSI, karena lokasinya yang sangat strategis memudahkan nasabah untuk menabung di BSI. Pelayanan yang baik memberikan kenyamanan serta kepuasan kepada para nasabahnya.

\section{REFERENCES}

Anas Sudijono, Pengantar Statistik Pendidikan, Jakarta : CV. Raja Grafindo persada, 2012.

Departemen Agama RI,Al-Qur'an dan Terjemah, (Jakarta: Pustaka assalam, 2011), Surat Al-Imran :130.

Masri Singarimbun dan Sofyan Effendi, eds, Metode Penelitian Survai, Jakarta : LP3ES, Cet. VIII, 2009.

Eddy Soetrisno,Kamus Populer Bahasa Indonesia, Bandung:Sinergi Pustaka Indonesia,2010.

M.B. Ali, dan Isman, William H, Kamus Lengkap Bahasa Indonesia, Bandung , Citra Umbara, 2011.

Muhammad, Dasar-dasar Manajemen Bank Syariah Edisi Revisi, Yogyakarta:UII Pres, 2014.

Mulyana, pengertian Persepsi dalam Masyarakat, Bandung:Rineka Cipta, 2016.

Nur Khalif Hazim dan A.R.Elhan, kamus Ilmiah Populer, Surabaya,karya Ilmu.2013.

P. Robin, Faktor persepsi, Jakarta:Gramedia, 2011.

Rakhmat, Filsafah persepsi, Yogyakarta:UII Pres, 2011.

Soejitno dan Abdul, Etika Perbankan, Jakarta:Batavia Pres,2014.

Slameto, Belajar dan Faktor-faktor yang mempengaruhinya, Jakarta: Rineka Cipta, 2010.

Tim Pustaka Agung Harapan,Kamus Ilmiah Populer,Surabaya:pustaka Agung Harapan,2012.

Ridwan, Belajar Mudah Penelitian, Bandung:Alfabeta,2014. 